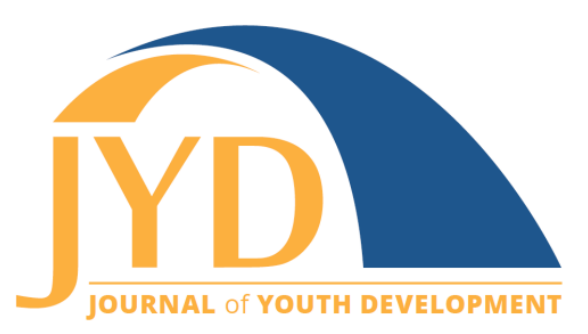

http://jyd. pitt. edu/ | Vol. 14 Issue 2 DOI 10.5195/jyd.2019.762 | ISSN 2325-4017 (online)

\title{
Let Your Past Struggles Serve as Your Future Fortitude: The Sinuous Journey of a Dreamer and a Doctor
}

\section{J. B. Rodriguez \\ D. X. Rodriguez}

\begin{abstract}
Immigration to the United States can often be a traumatic and difficult experience for families. Unfortunately, status and responsibilities of being undocumented presents obstacles that can be difficult to overcome for many young people. This young author describes the sacrifices her parents made for her to have educational opportunities and the struggles she went through to achieve her dreams of becoming a doctor. She skillfully highlights how being undocumented places additional barriers that often limit the chances of success and thriving.
\end{abstract}

Key words: determination, persistence, goals, achievement, undocumented

"I'm calling security for you" is a phrase most teenagers fear, but one I looked forward to while interning at the Children's Healthcare of Atlanta. As an international student I did not hold a state-issued identification (i.e., a driver's license) so I was not permitted to walk through the hospital alone but had to be escorted by a security guard to my designated room. I saw others' looks of disgust as I passed them in the hallways, but I smiled. I knew this wasn't the picturesque image every pre-med student has in mind when working at the hospital, but it was one of my greatest milestones. My internship, like my medical journey was far from conventional.

My inspiration to help others began at a young age in my hometown in Mexico. While growing up I was constantly tormented by unanswered questions in my community. Why did their child die from drinking the dam water? Why had their husband's foot gone numb? Why did their wife

(c) $\mathbf{E Y}$ New articles in this journal are licensed under a Creative Commons Attribution 4.0 License. This journal is published by the University Library System, University of Pittsburgh and is cosponsored by the University of Pittsburgh Press. The Journal of Youth Development is the official peer-reviewed publication of the National Association of Extension 4-H Agents and the National AfterSchool Association. 
The Sinuous Journey of a Dreamer and a Doctor

keep having miscarriages? The years passed and these questions remained unanswered; doctors refused to go to the poor stricken areas because they knew they wouldn't get paid. The only hope was the local curandera who relied on an array of herbs for medicine. I would cry to my mother with frustration and anger, why did nobody know the answers? There had to be an answer to help these people! My mom would look down, say it was God's will, and advise me to pray more.

My parents brought me to this country in hopes of providing me with a better future but this transition was not easy. I would come home crying, wearing a sweater around my waist to hide the urine that covered my pants. With my English vocabulary consisting of only two words, I was unable to tell my teachers I had to use the restroom, and being the only Hispanic in the school left me with nobody to ask for help. I remember crying angrily and asking my parents why they had brought me to this country. My father took my hand and said, "Because all the answers you are looking to help others are here, you just have to work very hard and look for them-in your school books, in your teachers, in your peers, in your struggles . . . work hard and you will find them."

My father's words never left my mind and he constantly reminded me of their presence in my life. I would ask him how I was going to pay for my school field trip or my school supplies for the upcoming year. He would always repeat the same phrase, "Trabaja duro, búscalo, y lo encontrarás" (Work hard, look for it, and you will find). My answer would always come, but not in an allowance like most children, but in helping him clean office buildings until two in the morning, or carrying two-by-fours in his construction job. At the end he'd always smile and say, "trabajaste duro y encontraste tu respuesta" (You worked hard and you found your answer), handing me a $\$ 10$ bill from his daily pay.

I tried my best to apply my parent's advice in my studies. the language barrier, I caught up to my classmates and soon excelled in many subjects. As I progressed in my schooling, I slowly started unveiling the answers. I was fascinated with my science classes that introduced me to diseases like cholera; I would think back to the polluted damn in Mexico and the constant diarrhea spells mothers would fear from drinking the water. I was shocked to learn that it is the male's sperm and his pairing of $X$ or $Y$ chromosomes that determines the sex of the baby. I thought of my neighbor who was constantly beaten by her husband for having five girls, as if it was her choice. I recognized many of the mental illness symptoms described in my psychology classes because I had seen so many of them back home. I remembered the neighborhood crazy man and many others who been cast out as sinners or possessed by evil spirits. The more I 
The Sinuous Journey of a Dreamer and a Doctor

learned, the greater the injustices became. It was here that I decided I would reach my goal of helping others through what I believed held many of the answers:science. I would become a doctor. I knew the next step to reaching this goal was to attend college, so I worked tirelessly during high school, trying my best to excel in all my classes and serving in numerous clubs and organizations to be the best applicant possible. When the application process started I was thrilled; I not only met the requirements of many colleges but I surpassed them. I was sure to be accepted. This came to an abrupt end when the state of Georgia passed a law banning all undocumented students from attending public universities. My dream was over, my college acceptance wasn't dependent on my achievements as a student but on my legal status. In despair I once again turned angrily to my parents, "Why did you bring me here? Why did you make me chase a dream I couldn't reach?" To my surprise my father simply repeated the same phrase, "Trabaja duro, búscalo y lo encontrarás."

I stormed to my room but soon realized he was right, I had worked hard but I hadn't looked. I began researching and learned that private universities accepted students despite their immigration status. I was thrilled-until I saw the price tag. I didn't let this discourage me, I applied to as many schools as I could and searched endlessly for scholarships that didn't require U.S. citizenship. My efforts did not go in vain, I received many acceptance letters along with numerous scholarships including one that covered all four years of my tuition. I was ecstatic, I would be able to continue pursuing my dream to become a doctor.

I entered college and for once felt normal, I thought all my struggles were over but I would soon find out they had just begun. The science classes I longed to be in turned into my worst nightmare, I was far from being the star student I had been in high school. I was lost in simple subjects the rest of the students seemed to be experts in. I would ask questions, go to all tutoring sessions, and yet I was not seeing results. In frustration, I went to visit my advisor. After I explained my dilemma, he said maybe I should take a step back and reevaluate my goals. He explained how competitive the medical field was: I had to start interning and shadowing which would be very difficult without a car and with my legal status. I had had to maintain high grades, which also presented to be a challenge since I still had to balance managing the family construction business. After doing that, the biggest problem would be finding schools that would accept me as an international student. Even after being accepted, I would have to find a way to pay for school out of pocket since I was ineligible for any government financial aid and scholarships for non-citizens were close to none. In despair I talked to as many people for guidance as I could find-peers, teachers, mentors-but I heard 
the same answer: "It is a wonderful dream but not realistic one, try something more on your level— maybe medical technician, social worker, school counselor."

Not ready to give up I decided to explore other public service careers; I took an internship in the family services department at the Latin American Association. I greatly cherished interacting with the families, yet I could see there was a great lack of medical aid available to the Hispanic population. Even living in the United States, going to the doctor was not a priority for Latinos due to the high healthcare costs and lack of health insurance.

I then worked as a camp counselor at an autistic children's camp. It was here that I reaffirmed my love of working with children and discovered the great benefits of therapy and social skill building. Though I was amazed by all the services and activities offered to the children, I longed for them to be offered in places where there was a lack of knowledge on developmental disorders - where children were misunderstood as weird and stupid, even by their own families.

I loved working in all these centers but I always found myself gravitating toward issues in the healthcare field. At the Latin American Association my hand shot up to volunteer in the annual health clinic. At the Marcus Autism Center I loved shadowing the psychiatrists when they came in to evaluate the children. I was fascinated by what they did, I felt like by just getting close to them I was somehow getting closer to my dream. Though I had to wake up at five in the morning, walk a mile, and take two buses to commute to Atlanta I cherished every day of work. Each center had been an ordeal to get into due to my legal status but by then I had established a system. I would call the coordinator in charge endlessly and bombard them with e-mails until I got a shot at speaking to them for the positions, after getting accepted I'd have to speak to the registration coordinator explaining my situation and praying they would give me a chance. After many, "I'm sorry we can't accept you," I would call the next center hoping this would be the one. At the Children's Healthcare Center I was accepted for the peer coach position, but after finding out my legal status they said they would not be able to pay me for the position like advertised. I was thrilled, I didn't care about the money. I would finally be in a hospital, working alongside doctors and being with patients and learning their stories.

On the first day at the hospital, the front desk asked me for my state-issued identification. After a long explanation, a series of phone calls and two security checks they agreed to let me in if a security guard escorted me to the center. I answered, "Sure, I love company!" The small moments of embarrassment, the dirty looks, and rejections were a small price to pay for my reward. I smiled because I had the opportunity many people in my country only dreamed of 
The Sinuous Journey of a Dreamer and a Doctor

reaching. I cherished every moment with the patients because it had cost me many sacrifices to be with them; this allowed me not only to sympathize with them, but in a small way to empathize with their struggles.

When I returned to school after the summer internship ended, once again I became confused. Though I was so grateful for all the opportunities I'd had over the summer, my peers bragged about research projects in Ivy League schools, missionary trips overseas, and paid jobs as EMTs-all things I couldn't apply for. Classes were still challenging, but my grades had greatly improved. Though I found myself getting some of the top scores in the class I also found myself studying twice as hard, tutoring more frequently, and always being the student with endless questions. I started resenting my tenacity and hard work. I began interpreting all these barriers as a sign from God that this wasn't for me. I didn't understand why I just couldn't be the regular pre-med student-a natural brainiac from a rich and educated family, excelling in extracurriculars, and sprinkled with impressive shadowing and internships experiences.

Following my father's advice once more, I looked. I read books of Dr. Alfredo Quinones, a neurosurgeon in John Hopkins Medical School who started out as migrant worker in California. I watched a movie about Dr. Joseph Moscati, a doctor who became a saint by giving everything to serve the poor. I read the book of Mother Teresa, who didn't need a medical degree to serve as a healer to treat the sick and injured. After reading their stories I found one thing in common, none of them lived a regular life; they were recognized for being different, for overcoming extraordinary battles, for surpassing obstacles the average person couldn't do. I thought about my life and my goal: to serve others through medicine. My goal couldn't be accomplished only by going to the top schools, or by having my named published in some fancy paper. A sick child wasn't going to ask me on his death bed if I graduated summa cum laude or if I was the chief resident. He was going to need my knowledge and compassion to treat him correctly. Grades and tests were qualifications needed to get into medical school, but they were not the ultimate and final goal; they were a form of preparation needed to reach that goal. I stopped constantly comparing myself to others and wishing I had it easier. I embraced my strengths and limitations and started working to balance them so I could do well in school and reach the next step in my goal to attend medical school.

Though my parents felt sorry that I had to mature at such a young age, I am grateful. I felt impotent and forlorn when confronting my adversities but I now realize the afflictions I experienced strengthened my character and gave me a sense of resiliency. I learned not to rely on others but to trust myself. I learned not to fear barriers but learned to overcome them. 
Many immigrants try to repress all memories and evidence of their pasts, of their poverty, hardships and adversities. They feel ashamed of these experiences and cringe at any recollection of them. I hear numerous Hispanic kids deny their roots. They forget about their past and the sacrifices that were made to offer them the comfortable lifestyles they indulge in. I am proud to be Mexican American. I feel privileged to have been confronted with barriers at a young age because it is thanks to them that I am the person I am now. I don't feel ashamed of having been considered the stupid one in the class or having had people laugh at me because of my accent. I am not embarrassed to say I cleaned bathrooms and swept floors to be where I am now. It is my past struggles that give me the fortitude to overcome my present ones. Whenever I am presented with a new dilemma, I remember the poignant afflictions my parents and I endured and overcame, and this gives me the hope and courage to prevail through any obstacles that cross my path.

\section{Acknowledgements:}

The authors stand in solidarity with those who are in "the shadows" and as such, have chosen to only give their initials. Que aquellos que viven en las sombras sean animados, sabiendo que nuestra esperanza es lo que proyecta una luz sobre nuestsras sombras. (May those who live in the shadows be encouraged, knowing that our hope is what casts a light over our shadows.) 